Diabetologia 10, $567-579(1974)$

(C) by Springer-Verlag 1974

\title{
Morphologic Abnormalities Observed in Retina, Pancreas and Kidney of Diabetic Chinese Hamsters
}

\author{
M. G. Soret, W.E. Dulin, J. Mathews, G.C. Gerritsen \\ Pathology and Toxicology Research and Diabetes and Atherosclerosis Research, The Upjohn Company, Kalamazoo, \\ Mich. 49001, USA
}

Summary. Intracellular glycogen deposits were consistently found in the retina, kidney and pancreatic islets of diabetic-ketonuric Chinese hamsters. Accumulation of glycogen in the outer nuclear layer of the retina was mostly associated with severity of the disease, but was not related to age or sex. The type of retinal cell involved in the accumulation of glycogen was not clearly established. However, the position of the affected cell, side by side with retinal neurons, suggests that the glycogen deposits were within Müller cells. These giant glias normally synthesize and store glycogen. All ketonuric Chinese hamsters examined showed some accumulation of glycogen in distal tubules of the kidney. This abnormal glycogen was not found in glucosuric non-ketonuric or in non- diabetic Chinese hamsters. Variable amounts of glycogen were found in $\beta$ cells of pancreatic islets of diabetic ham. sters, as reported by others. However, accumulation of glycogen was also found in $\alpha$ and $D$ islet cells from 2 middle aged Chinese hamsters with long term glucosuria and recent ketonuria. Abnormal glucose and glycogen metabolism seem to play an important role in the pathogenesis of diabetes in the Chinese hamster.

Key words: Chinese hamster, spontaneous diabetes, glucosuria, ketonuria, glycogen, glycogen accumulation, retina, Müller cell, kidney, distal tubule, pancreatic islet, $\alpha$ cell, $\beta$ cell, $\mathrm{D}$ cell, electron microscopy.

\section{Introduction}

Since the introduction of the spontaneously diabetic Chinese hamster (Criselulus griseus) as an animal model of the human disease $[7,11]$ relatively few morphologic studies have been made on this animal.

Most of the structural studies of the Chinese hamster have been made on the pancreatic islets $[2,3,4,9,10,12,13]$ while limited attention has been given to the kidney $[5,14]$ and the eye $[6,15,16]$.

This report is primarily concerned with previously described [16] retinal lesions found in ketonuric Chinese hamsters. The initial observations have been confirmed and extended by study of larger groups of hamsters of varied ages, duration of diabetes and metabolic conditions. The kidneys and pancreata of the same animals were examined and some observations described.

\section{Methods}

A total of 158 hamsters were studied, including 61 nondiabetics, 31 non-ketonuric diabetics and 65 ketonurics. All of these animals were tested biweekly for urine glucose from the age of 14 days and for ketonuria, after maximal positive glucose test, until sacrifice. Those hamsters showing continuous glucosuria with Testape ${ }^{\circledR}$ were defined as diabetics and those diabetics presenting a continuous rating of "large" by the use of Ketostix ${ }^{\circledR}$ were defined as ketonurics. Animals defined as diabetic and/or ketonuric had hyperglycemia and relative insulin deficiency as previously reported [7]. Nondiabetic
Chinese hamsters were from sublines which have been free of diabetes for at least 5 generations of continuous brother-sister matings. A few "aglucosuric" animals from highly inbred sublines which produce diabetics were also studied.

Types and number of animals from which tissues were taken for study are summarized in Table 1. Animals were matched for sex and as close as possible for age. An attempt was made to match ketonurics with animals of the same age and duration of diabetes (Table 2). Most of the animals were within the $9-16$ month age range, the youngest animal was a 2 month old diabetic, ketonuric for 15 days prior to sacrifice and the oldest was a 30 month old animal showing intermittent glucosuria for a period of 27 months. Sixty-three percent of the animals were female.

Eyes, kidneys and pancreata were removed from the animals immediately after exsanguination followed by decapitation and the tissues were processed as follows: For light microscopy, one intact eye was fixed in Bouin's; small samples of kidney and pancreas were fixed in Bouin's, methanol and $10 \%$ neutral formalin. These materials were embedded in paraffin and serial 5 micron sections were stained with hematoxylin-eosin and allochrome (PAS) (eyes and kidneys) and with aldehyde fuchsin-light green-orange $G$ (pancreata).

For electron microscopy, the posterior half from one eye was first immersed in $2 \%$ glutaraldehyde (in 0.1 M phosphate buffer, $\mathrm{pH}$ 7.4) and within $1 \mathrm{~h}$ the retina was separated from the choroid and cut in small sectors, the apexes coinciding with the optic nerve. After $3-4 \mathrm{~h}$ of glutaraldehyde fixation, the retinas were rinsed in phosphate buffer, post-fixed 
for $1.5 \mathrm{~h}$ in $1 \%$ osmium tetroxide and processed for Epon embeddment. Small blocks of kidney and pancreata were also fixed in glutaraldehyde, postfixed in osmium and embedded in Epon. One micron sections of materials embedded in Epon were stained with toluidin blue or PAS for examination under light histologic preparations. These layers are, proceeding from the outer surface to the inner: pigmented cell layer $(P)$, rod layer $(\mathbf{R})$, external limiting membrane (ELM), outer nuclear layer (ONL), outer plexiform layer (OPL), inner nuclear layer (INL), inner plexiform layer (IPL), ganglion cell layer (GCL), nerve

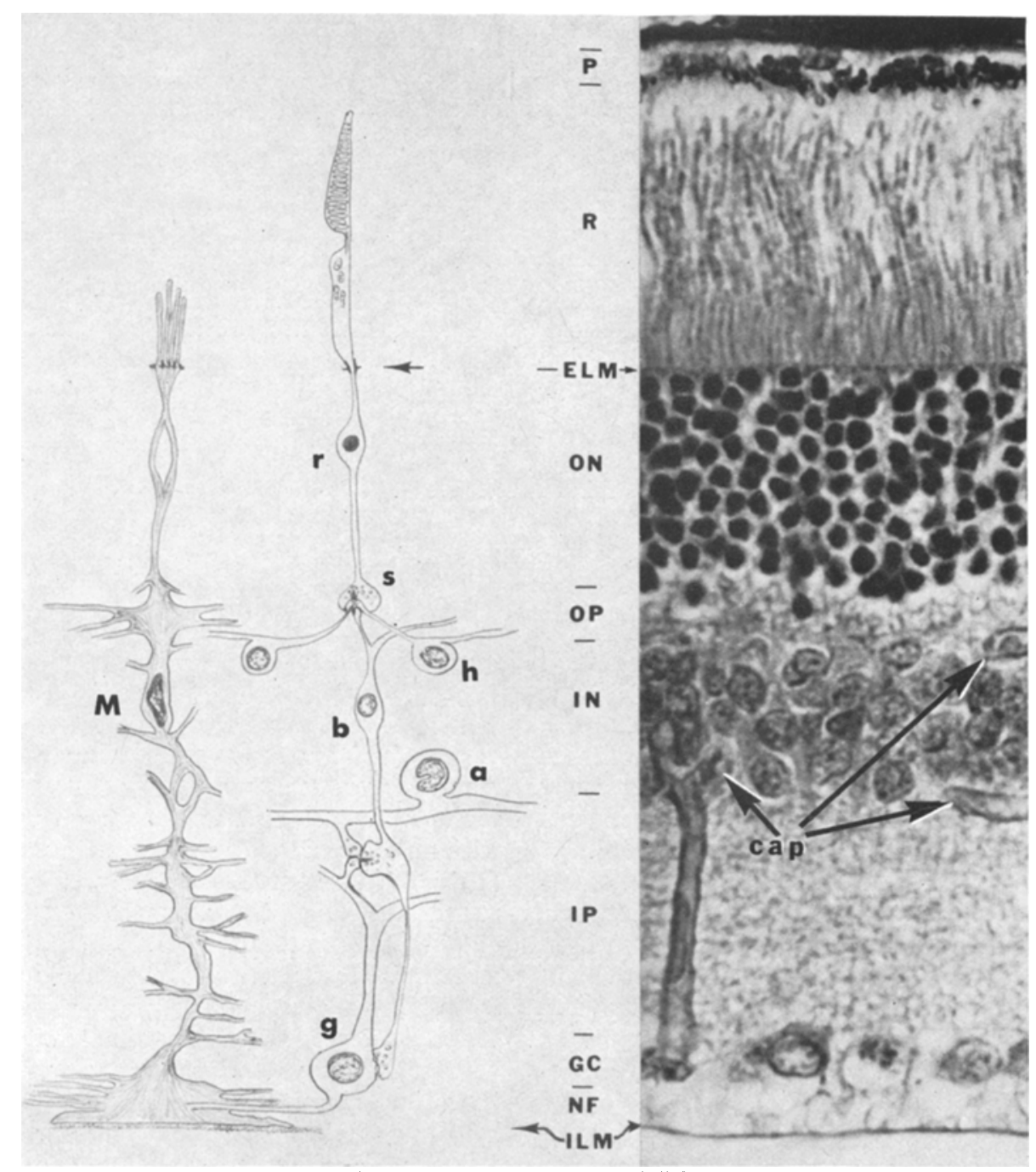

Fig. 1. Structure of the Chinese hamster retina. $\mathrm{P}=$ pigment cell layer, $\mathrm{R}=$ rod layer, ELM $=$ external limiting membrane, $\mathrm{ON}=$ outer nuclear layer, $\mathrm{OP}=$ outer plexiform layer, $\mathrm{IN}=$ inner nuclear layer, IP $=$ inner plexiform layer, $\mathrm{GC}=$ ganglion cell layer, $\mathrm{NF}=$ nerve fiber layer, $\mathrm{ILM}=$ internal limiting membrane, $\mathbf{r}==$ receptor cell, $\mathrm{b}=$ bipolar cell, $\mathrm{g}=$ ganglion cell, $\mathrm{h}=$ horizontal cell, $\mathrm{a}=$ amacrine cell, $\mathrm{M}=$ Müller cell, $\mathrm{s}=$ spherule of receptor cell, cap = capillary. [Schematic drawings modified from Dowling, J.E., Boycott, B.B.: Proc. roy. Soc. London (Biol.) 166, 80-11. (1966) and from: Histology of the Human Eye. M.J. Hogan, J.A. Alvarado, J.E. Weddell (eds.) London: W.B. Saunders Co. 1971]

microscopy. Thin sections of selected areas were stained with uranyl acetate and lead citrate and examined in a Philips 301 electron microscope.

\section{Results}

The nondiabetic Chinese hamster retina is shown in Fig. 1. Several distinct layers can be recognized in fiber layer (NFL) and internal limiting membrane (ILI)

Five of the six main types of retinal cells are conducting cells, either sensory receptors or neurons. The conductive elements of the retina are: the receptor cells, of the rod type only, which occupy most of the external half of the retinal thickness, including the 
rod and the outer nuclear layers; the bipolar, horizontal and amacrine cells, located in the inner nuclear layer; and the ganglion cells which form a single row near the inner retined surface, e.g. the vines retined surface. Synapses between receptor cell axonal terminations (spherules), bipolar cell dendrites and horizontal cell are in charge of the visual path, the horizontal and amacrine cells are in charge of horizontal integration of the vision.

The sixth retinal cell type is the Müller cell which has important nutritive and supportive functions. They are giant glias which extend from the inner

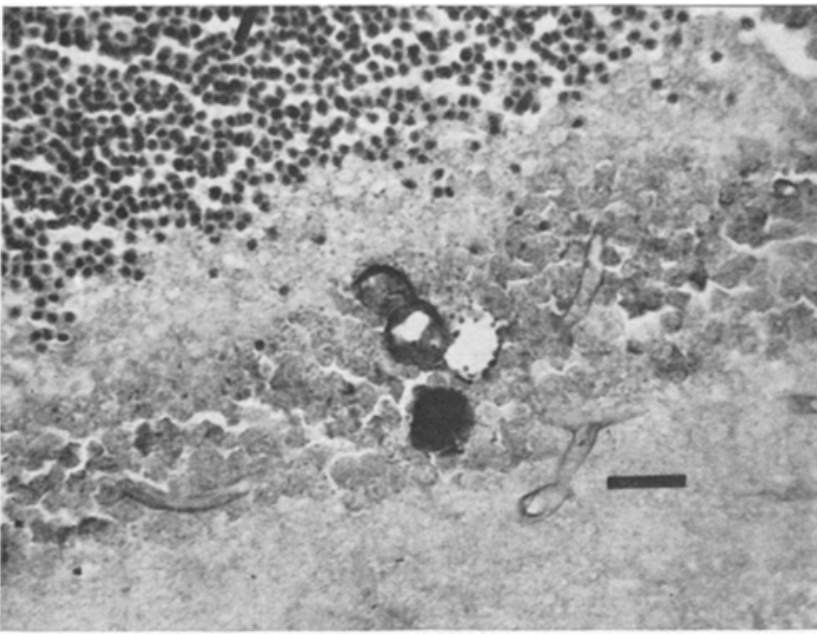

a

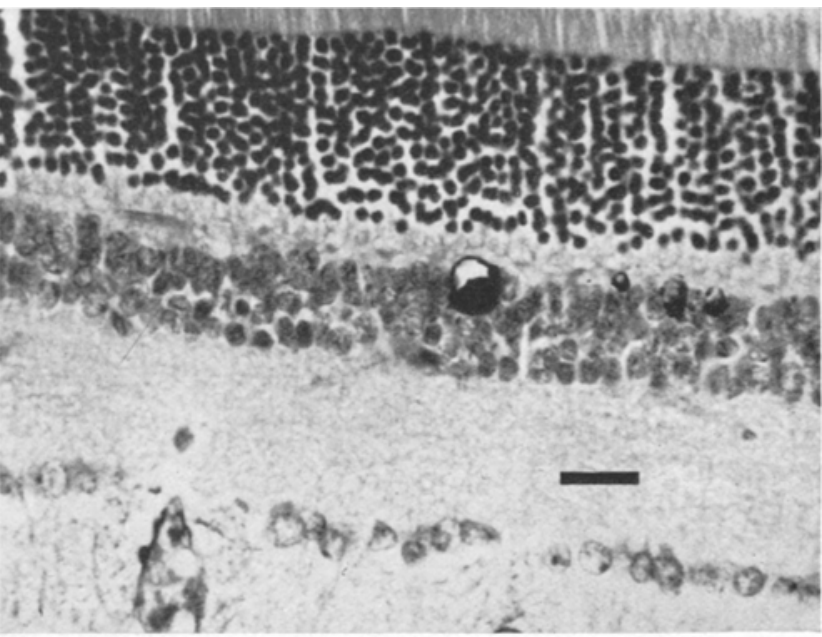

$\mathrm{b}$

Fig. 2. Retinal lesions found in spontaneously diabetic Chinese hamster. a) Large deposits of PAS + material in the INL. b) Masses of PAS + material in the INL, impinging on the OPL. Bar $=20 \mu$

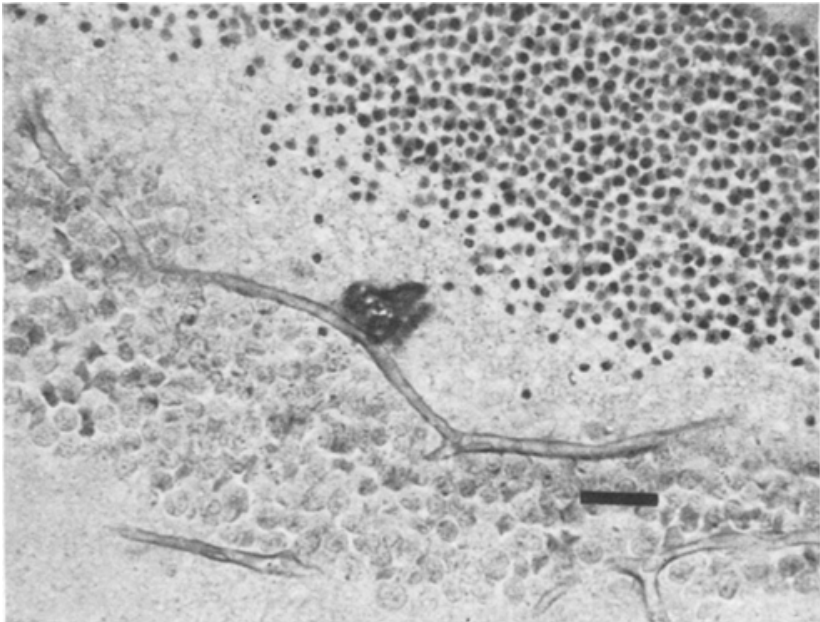

a

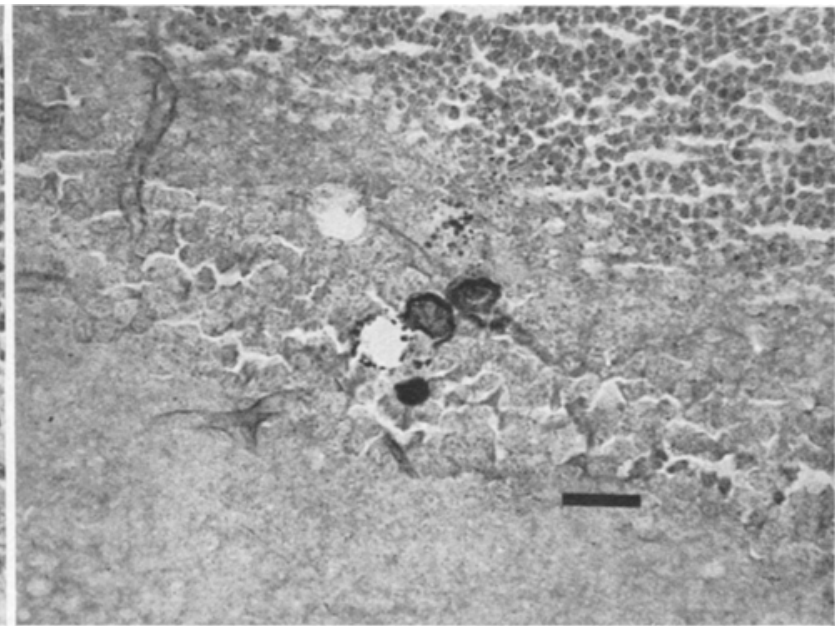

b

Fig. 3. Retinal lesions near capillaries, in spontaneously diabetic Chinese hamsters. a) The lesion, a PAS + mass, is located in the OPL. b) Several PAS + masses in the INL. Some of the lesions appear to be in the path of capillaries. $\mathrm{Bar}=20 \mu$

processes take place in the outer plexiform layer. Synapses between bipolar cell axons, amacrine cell processes and ganglion cell dendrites occur in the inner plexiform layer. Axons of the ganglion cells run along the nerve fiber layer and bundle together to form the optic nerve. While the rod, bipolar and ganglion cells limiting membrane to beyond the external limiting membrane. These giant glias fill most interneuronal spaces and insulate neurons from each other and from most of the vascular bed. An important function of the Müller cells is the synthesis and storage of glycogen for conversion into glucose to provide energy to 
adjacent neurons [8]. The main bodies and nuclei of Müller cells are located in the INL, but their branches extend in every direction, surrounding the neural processes and all small vessels.

Nutritional supply of the retina is provided by the retinal vessels and by the choriocapillaris. Only the internal half of the retina is vascularized. Retinal vessels run along the NFL, branch outwardly through the IPL and end in a capillary bed which does not extend beyond the inner area of the OPL. The external

Table 1. Tabulation of various metabolic types of Chinese hamsters from which tissues were studied. The Numbers indicate the number of animals studied

\begin{tabular}{|c|c|c|c|c|c|c|}
\hline \multirow{2}{*}{ Tissue studied } & \multirow{2}{*}{ Methoda } & \multicolumn{5}{|c|}{ Number of animals of each type } \\
\hline & & $\overline{\text { Non diabetics }}$ & Aglucosurics & Diabetics & Ketonurics & Total \\
\hline Retina & $\begin{array}{l}\mathrm{LM} \\
\mathrm{EM}\end{array}$ & $\begin{array}{r}59 \\
3\end{array}$ & $\begin{array}{l}3 \\
0\end{array}$ & $\begin{array}{r}31 \\
2\end{array}$ & $\begin{array}{l}63 \\
10\end{array}$ & $\begin{array}{r}156 \\
15\end{array}$ \\
\hline Kidney & $\begin{array}{l}\text { LM } \\
\text { EM }\end{array}$ & $\begin{array}{r}42 \\
5\end{array}$ & $\begin{array}{l}3 \\
0\end{array}$ & $\begin{array}{r}10 \\
2\end{array}$ & $\begin{array}{r}44 \\
5\end{array}$ & $\begin{array}{l}99 \\
12\end{array}$ \\
\hline Pancreas & $\begin{array}{l}\text { LM } \\
\text { EM }\end{array}$ & $\begin{array}{r}35 \\
6\end{array}$ & $\begin{array}{l}3 \\
0\end{array}$ & $\begin{array}{l}0 \\
0\end{array}$ & $\begin{array}{r}39 \\
8\end{array}$ & $\begin{array}{l}77 \\
14\end{array}$ \\
\hline
\end{tabular}

a LM = Light microscopy

$\mathrm{EM}=$ Electron microscopy

Table 2. Number, sex and distribution according to metabolic condition of Chinese hamsters used. Range of age and duration of diabetes or ketosis are expressed in months between parentheses

\begin{tabular}{|c|c|c|c|c|c|c|c|c|c|c|c|c|c|}
\hline \multirow{3}{*}{ Age range } & \multirow{2}{*}{\multicolumn{2}{|c|}{$\begin{array}{l}\text { Non } \\
\text { diabetic } \\
\text { Sex }\end{array}$}} & \multirow{2}{*}{\multicolumn{2}{|c|}{$\begin{array}{l}\text { Aglueos- } \\
\text { urics } \\
\text { Sex }\end{array}$}} & \multicolumn{3}{|c|}{ Diabetics } & \multicolumn{3}{|c|}{ Ketonurics } & \multirow{2}{*}{\multicolumn{2}{|c|}{$\begin{array}{l}\text { Total by } \\
\text { sex }\end{array}$}} & \multirow{3}{*}{$\begin{array}{l}\text { Total by } \\
\text { age range }\end{array}$} \\
\hline & & & & & \multicolumn{2}{|c|}{ Sex } & \multirow[t]{2}{*}{ (duration } & \multicolumn{2}{|c|}{$\overline{\text { Sex }}$} & \multirow[t]{2}{*}{ (duration) } & & & \\
\hline & $\bar{d}$ & 우 & $\overline{0}$ & $\bar{q}$ & 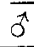 & $\bar{q}$ & & $\widehat{\sigma}$ & q & & $\bar{\alpha}$ & 우 & \\
\hline$(2-8)$ & 7 & 2 & 0 & 0 & 4 & 1 & $(1-5)$ & 6 & 5 & $(0.5-6)$ & 17 & 8 & 25 \\
\hline$(9-16)$ & 14 & 28 & 3 & 0 & 3 & 13 & $(5-16)$ & 16 & 27 & $(3-9)$ & 36 & 68 & 104 \\
\hline$(17-29)$ & 2 & 6 & 0 & 0 & 1 & 4 & $(12-27)$ & 2 & 9 & $(2-9)$ & 5 & 19 & 24 \\
\hline$(22-30)$ & 0 & 0 & 0 & 0 & 1 & 4 & (intermtnt. ${ }^{a}$ ) & 0 & 0 & & 1 & 4 & 5 \\
\hline & & & & & & & & & & Totals & 59 & 99 & 158 \\
\hline
\end{tabular}

a jntermittent

Table 3. Incidence of retinal lesions in Chinese hamsters of various ages and duration of diabetes and ketosis

\begin{tabular}{|c|c|c|c|c|c|c|}
\hline \multirow{3}{*}{ Type } & \multicolumn{6}{|c|}{ Range - months } \\
\hline & \multirow[t]{2}{*}{$\overline{\text { Age }}$} & \multicolumn{2}{|l|}{ Duration } & \multirow{2}{*}{\multicolumn{2}{|c|}{ Lesions/Total }} & \multirow[t]{2}{*}{$\%$} \\
\hline & & Diabetes & Ketonuria & & & \\
\hline $\begin{array}{l}\text { Non-diabetics } \\
\text { Non-diabotics } \\
\text { Non-diabetics } \\
\text { Aglucosurics }\end{array}$ & $\begin{array}{r}2-5 \\
6-10 \\
11-28 \\
15\end{array}$ & $\begin{array}{l}- \\
- \\
-\end{array}$ & $\begin{array}{l}- \\
- \\
-\end{array}$ & $\begin{array}{l}0 / 4 \\
0 / 13 \\
0 / 42 \\
0 / 3\end{array}$ & $0 / 62$ & 0 \\
\hline $\begin{array}{l}\text { Diabetics, continuous } \\
\text { Diabetics, continuous } \\
\text { Diabetics, continuous } \\
\text { Diabetics, intermittent }\end{array}$ & $\begin{array}{c}5 \\
7-9 \\
12-29 \\
22-30\end{array}$ & $\begin{array}{l}1-4 \\
5-7 \\
10-27 \\
\text { intermittent }\end{array}$ & $\begin{array}{l}- \\
- \\
-\end{array}$ & $\begin{array}{l}0 / 2 \\
0 / 5 \\
3 / 19 \\
1 / 5\end{array}$ & $4 / 31$ & 12.9 \\
\hline $\begin{array}{l}\text { Ketonurics, continuous } \\
\text { Ketonurics, continuous } \\
\text { Ketonuries, mild, short } \\
\text { Ketonurics, intermittent }\end{array}$ & $\begin{array}{r}5-9 \\
10-29 \\
2-15 \\
13\end{array}$ & $\begin{array}{l}4-8 \\
6-17 \\
1-14 \\
11\end{array}$ & $\begin{array}{l}1-3 \\
1-13 \\
0.5-2 \\
6-8\end{array}$ & $\begin{array}{c}6 / 8 \\
44 / 45 \\
0 / 8 \\
0 / 2\end{array}$ & $50 / 63$ & 70.4 \\
\hline
\end{tabular}

Fig. 4. Deposits of glycogen (gl) in the INL of a ketonuric Chinese hamster. The large deposit extends into the OPL but does not reach the spherules (s) of the receptor cells (top right). Bar $=\mathbf{1} \mu$

Fig. 5. Detail of an area adjacent to the one in Fig. 4. The deposit (gl) is an intracellular mass of monoparticulate and aggregated glycogen, within a probable Müller cell process (M?). A bipolar dendrite (d) at the center. A normal Müller cell process (M) surrounds the unaffected capillary (c). Bar $=1 \mu$ 


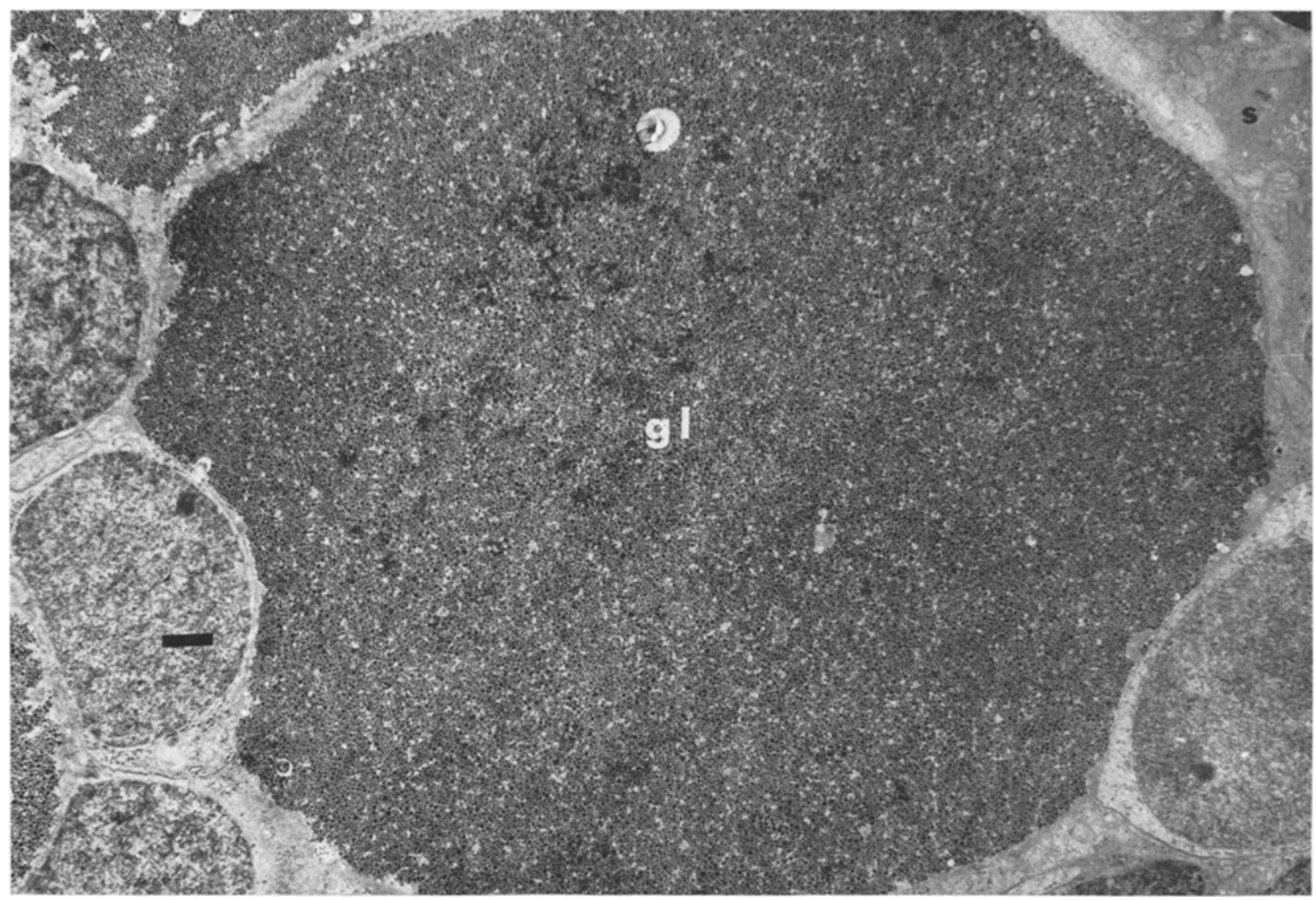

Fig. 4

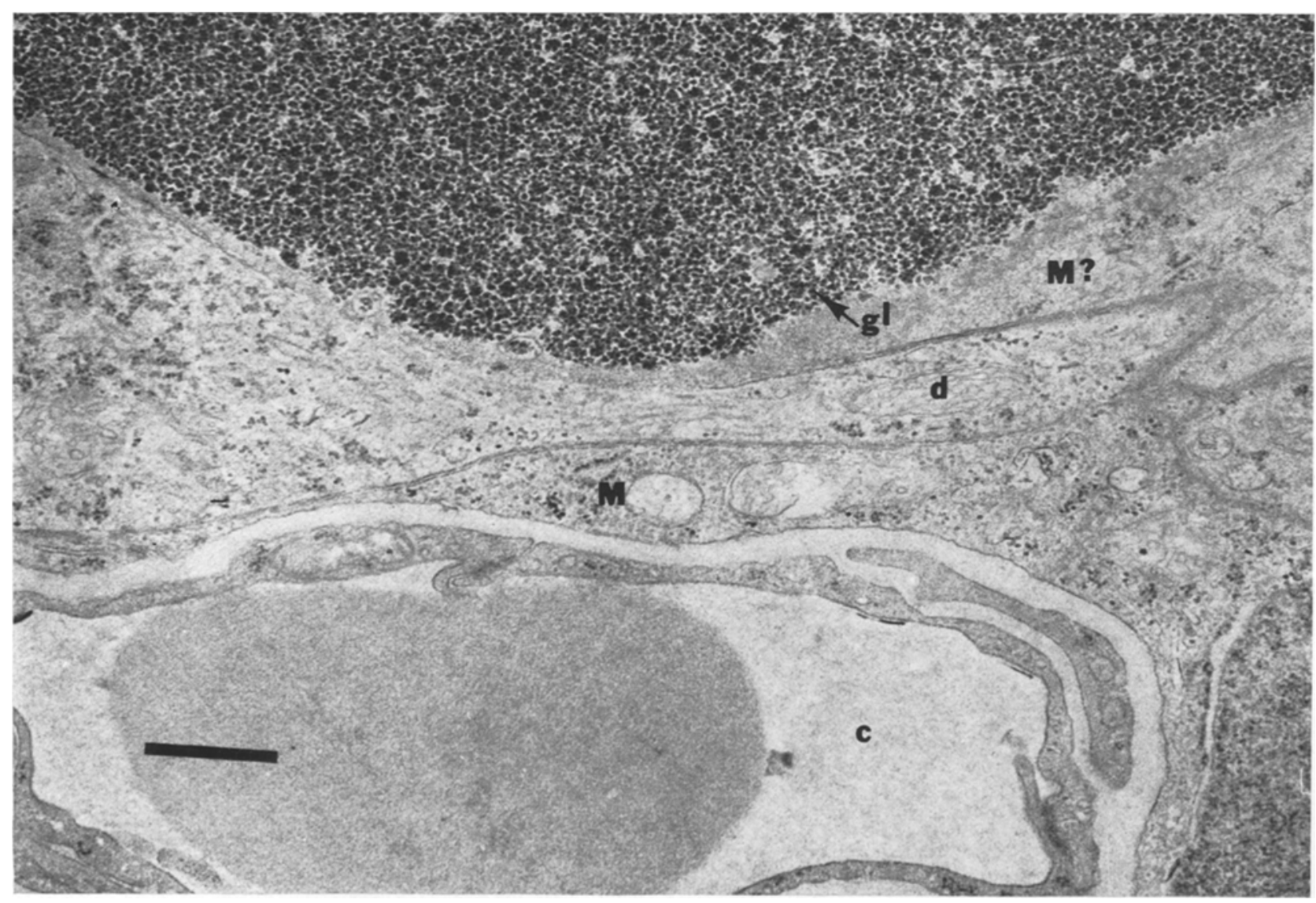

Fig. 5 
layers, including the entirety of the receptor cells and the pigmented epithelium are nourished by the choriocapillaris.

An unusual type of lesion was found in most severely diabetic Chinese hamsters [16]. Under light microscopy (Fig. 2a) these lesions consisted of PAS + masses of variable size, isolated or in clusters, and located for the most part in the INL. The areas adjacent to these masses were apparently unaffected in spite of the displacement of the normal elements. Some of the PAS stained masses were located in the area of the OPL (Fig. 2b) but never impinged on the area occupied by the rod spherules. Rough handling of the sections during the mounting process would displace some of the PAS + masses from the original location, as shown in Fig. 2a, leaving an empty space in the retinal section. These masses were found to be amylase digestible. Though no evidence of capillary damage was found, some of the masses appeared to be in the path of or very close to capillaries (Figs. 3a,b). To clarify the question of capillary involvement, a preparation similar to that shown in Fig. 3a was removed from the glass slide with Epon and ultra-thin sections of the re-embedded material were examined by electron microscopy. The PAS + material was found to be a mass of glycogen which had no direct connection with the nearby capillary.

The incidence of retinal lesions in the various types of Chinese hamsters studied is furnished in Table 3. The highest incidence $(70.4 \%$ ) was observed among ketonuries. The ketonurics which did not have retinopathy had either short term, mild or inter-

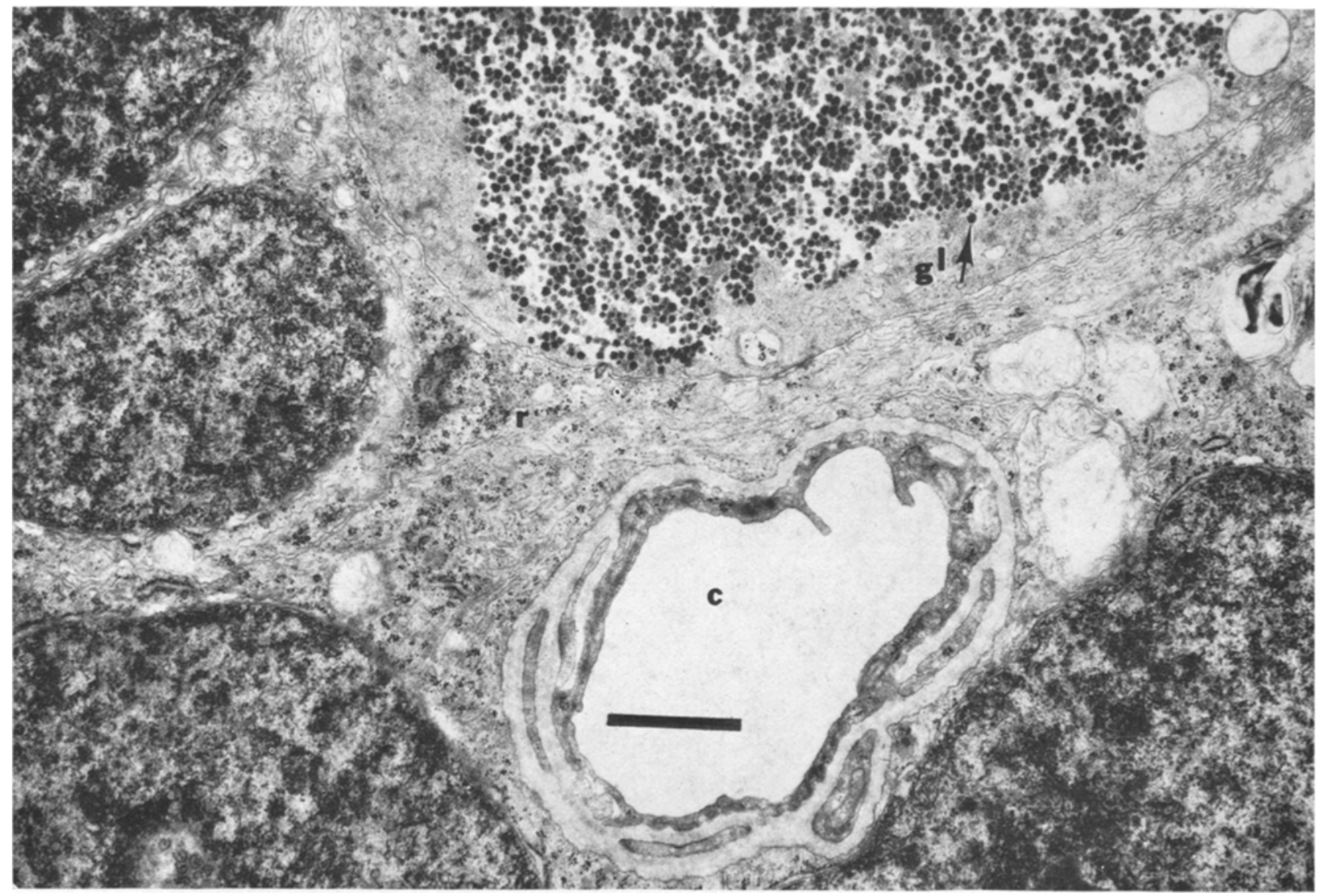

Fig. 6

Figs. 6 and 7. These photographs were taken from the same retina at the same magnification. Chinese hamster 11 month old, 9 month diabetic, 6 month ketoriuric

Fig. 6. A large intracytoplasmic deposit of $\alpha$-glycogen rosettes (gl), measuring about 750 A. Compare to ribosomes (r). Adjacent cells and capillary (c) are unaffected. Bar $=1 \mu$

Fig. 7. Deposit of $\beta$-glycogen particles, measuring each about $300 \AA$. The membrane of the cell enclosing the deposit appears intact in some areas (short arrow), but is missing in other areas (long arrow). Bar $=1 \mu$

Fig. 8. Degenerating Müller cell expansion (M) at the inner retina. Compare with normal portions of other Müller cells $\left(\mathrm{M}^{\prime}\right)$. ILM $=$ internal limiting membrane. Bar $=1 \mu$ 


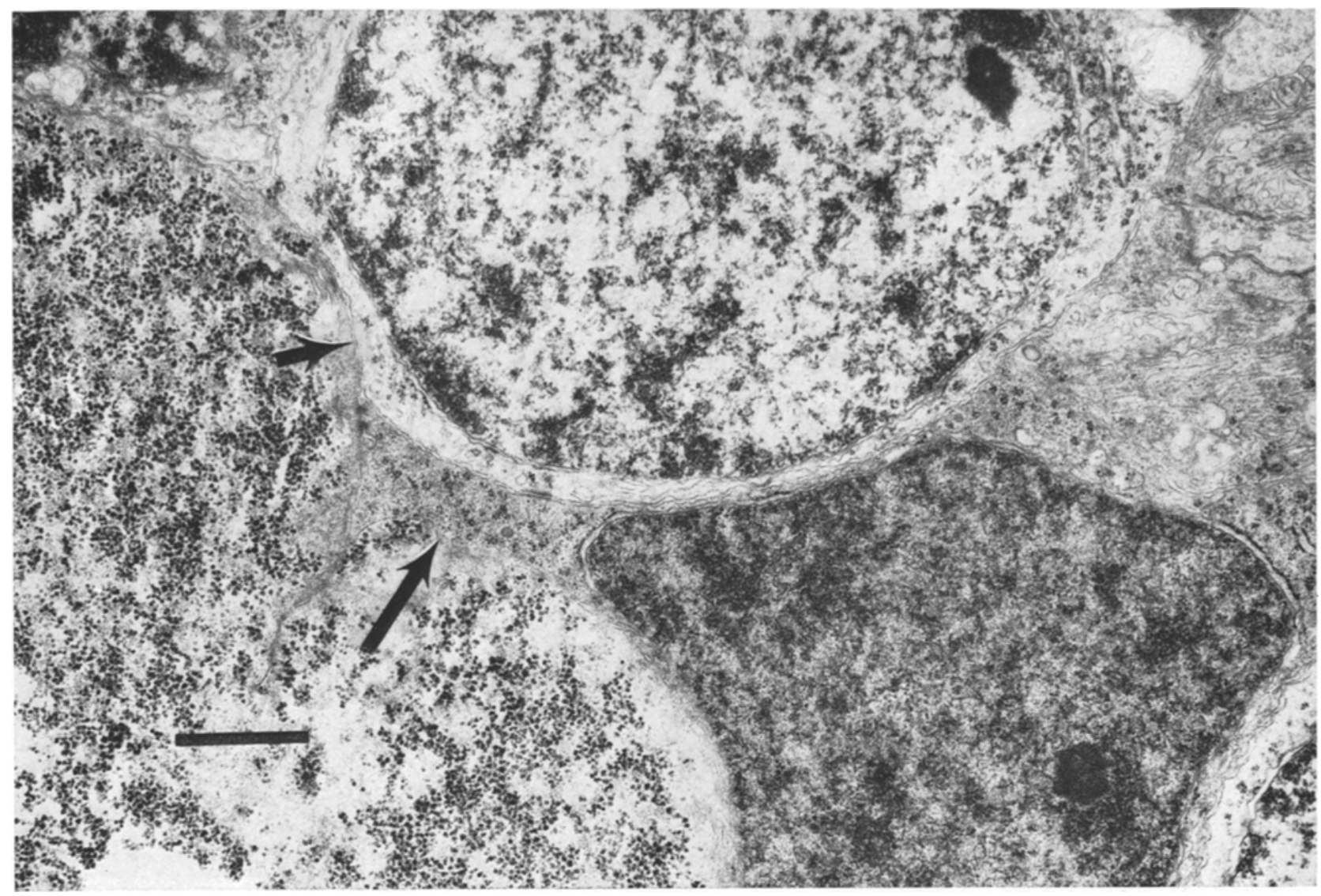

Fig. 7

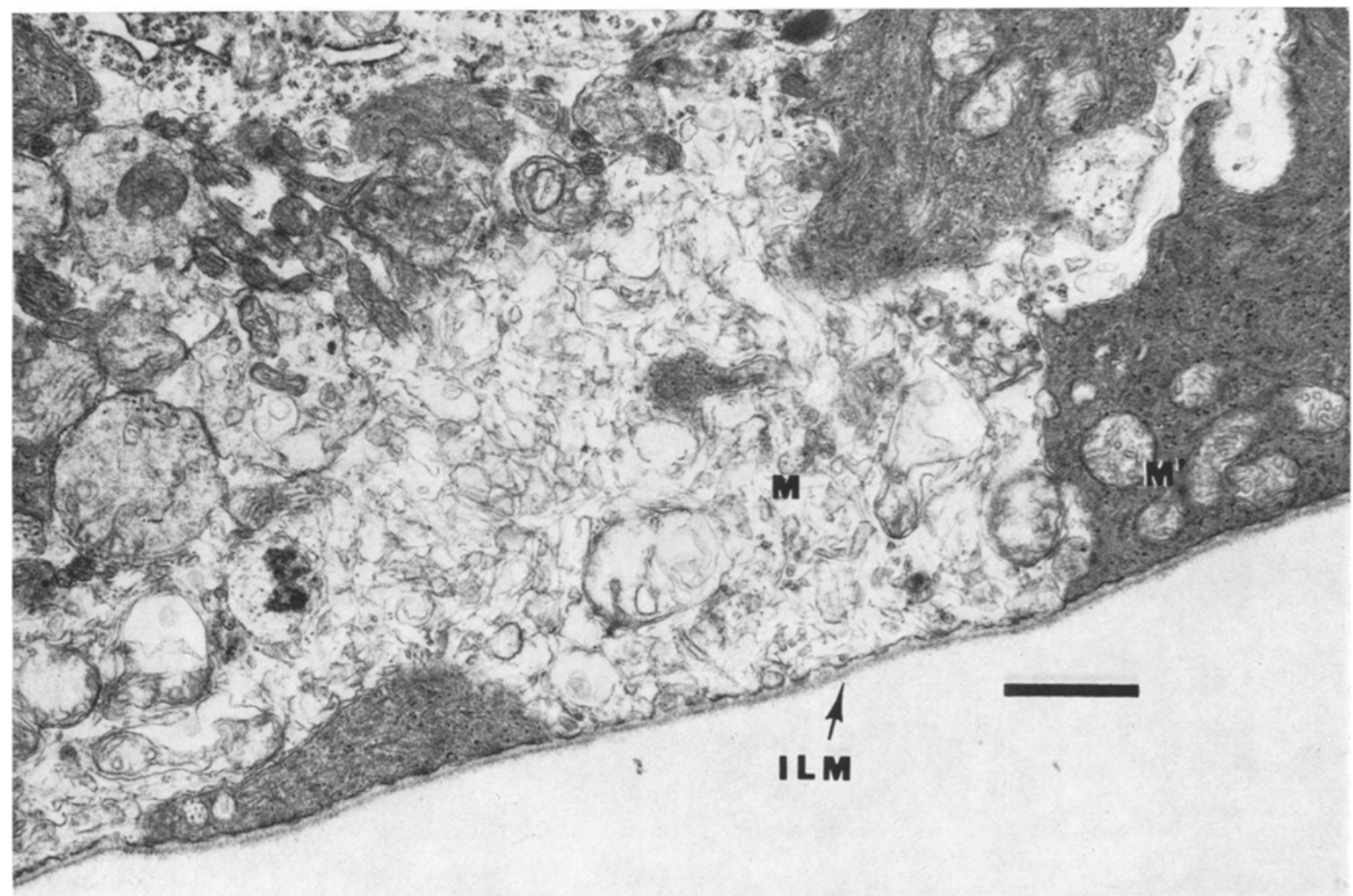

Fig. 8 
mittent ketonuria. By contrast, $94 \%$ of the diabetics with continuous ketonuria for a minimum of one month had retinopathy. Among diabeties, there was only a $13 \%$ incidence of retinal lesions which were observed in animals which had continuous glucosuria for at least 10 months. No retinal changes were found in nondiabetics or aglucosurics. These retinal lesions consistently found in most severe ketonuric hamsters, were never numerous or widespread; therefore a minimum of 100 serial paraffin sections were examined before recording a retina as negative.

The nature and location of the lesions were studied with the electron microscope. Fig. 4 shows that the abnormal masses of granular material were membrane bound and therefore considered to be intracellular in spite of their size. The largest deposit extends outward into the OPL approaching but not reaching the spherules of the receptor cells. Fig. 5 shows a detail of an area adjacent to the one in Fig. 4. The granular material is identified as a mass of monoparticulate and aggregated $\beta$ glycogen particles averaging about $280 \AA$ each and is surrounded by a narrow strip of cytoplasm. A capillary near the deposit appears unaffected. The process of a Müller cell, intimately applied to the capillary basement membrane, separates the capillary from the dendritic

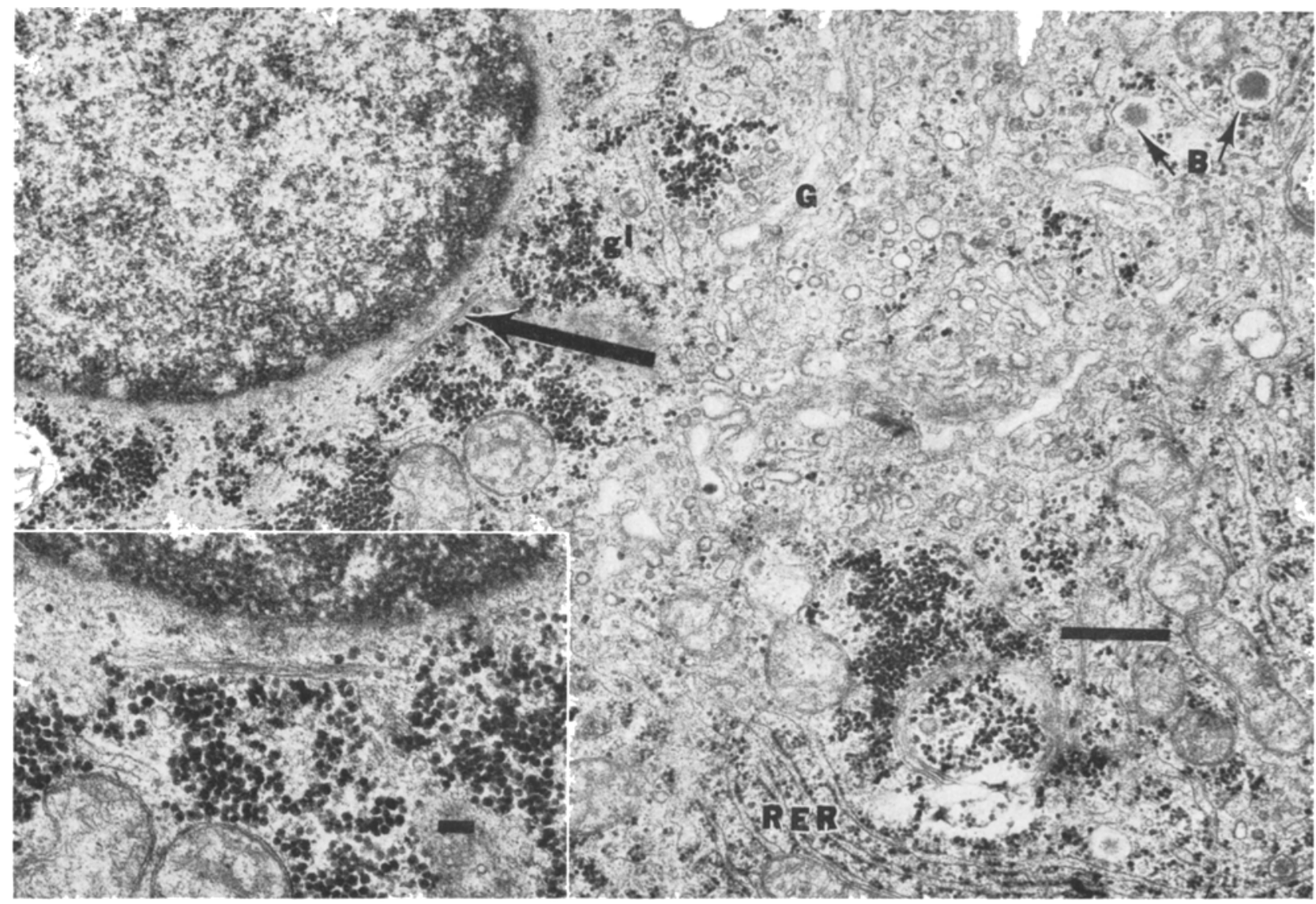

Fig. 9. Pancreatic $\beta$ cell in a ketotic Chinese hamster. The cell is almost totally degranulated. $\beta$ granules (B) have low electron density. Golgi apparatus (G) and rough endoplasmic reticulum (RER) are well developed. Glycogen $=$ gl. A thin bundle of perinuclear fibrils, rarely found in pancreatic $\beta$ cells of Chinese hamsters is shown (large arrow). Bar $=0.5 \mu$. Insert: A detail of the bundle of perinuclear fibrils and glycogen granules, at higher magnification. Bar $=0.1 \mu$

Fig. 10. Pancreatic $\alpha$ cell of a diabetic Chinese hamster, 14 month old, 12 month diabetic and less than 1 month ketonuric. Glycogen particles (gl) in close proximity to perinuclear fibril bundle (large arrow). $\alpha$ granules $=\mathrm{A}$; Bar $=0.5 \mu$. Bundle of perinuclear fibrils and glucagon granules, at higher magnification. Bar $=0.1 \mu$

Figs. $11 \mathrm{a}$ and $11 \mathrm{~b}$. Pancreatic $\alpha$ cell of a 14 month old Chinese hamster, 12 month diabetic and less than a month ketonuric

Fig. 11a) Glycogenosomes and free monoparticulate glycogen in close proximity to $\alpha$ granules (arrows). Notice 2 characteristic $\alpha$ cell phagosomes (ph). Portions of a $D$ cell (D) and a $\beta$ cell (B) are shown. Bar $=0.5 \mu$ 


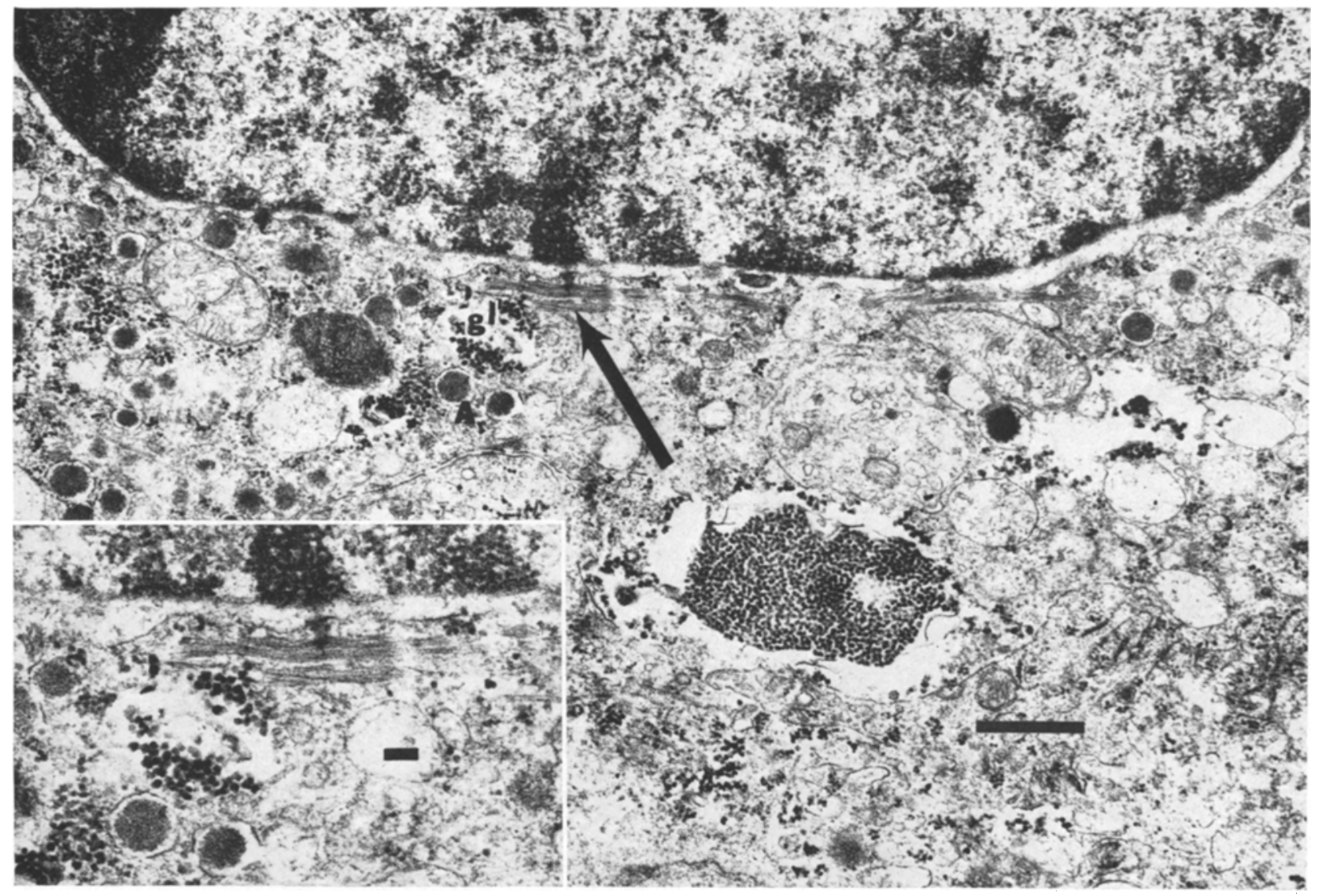

Fig. 10

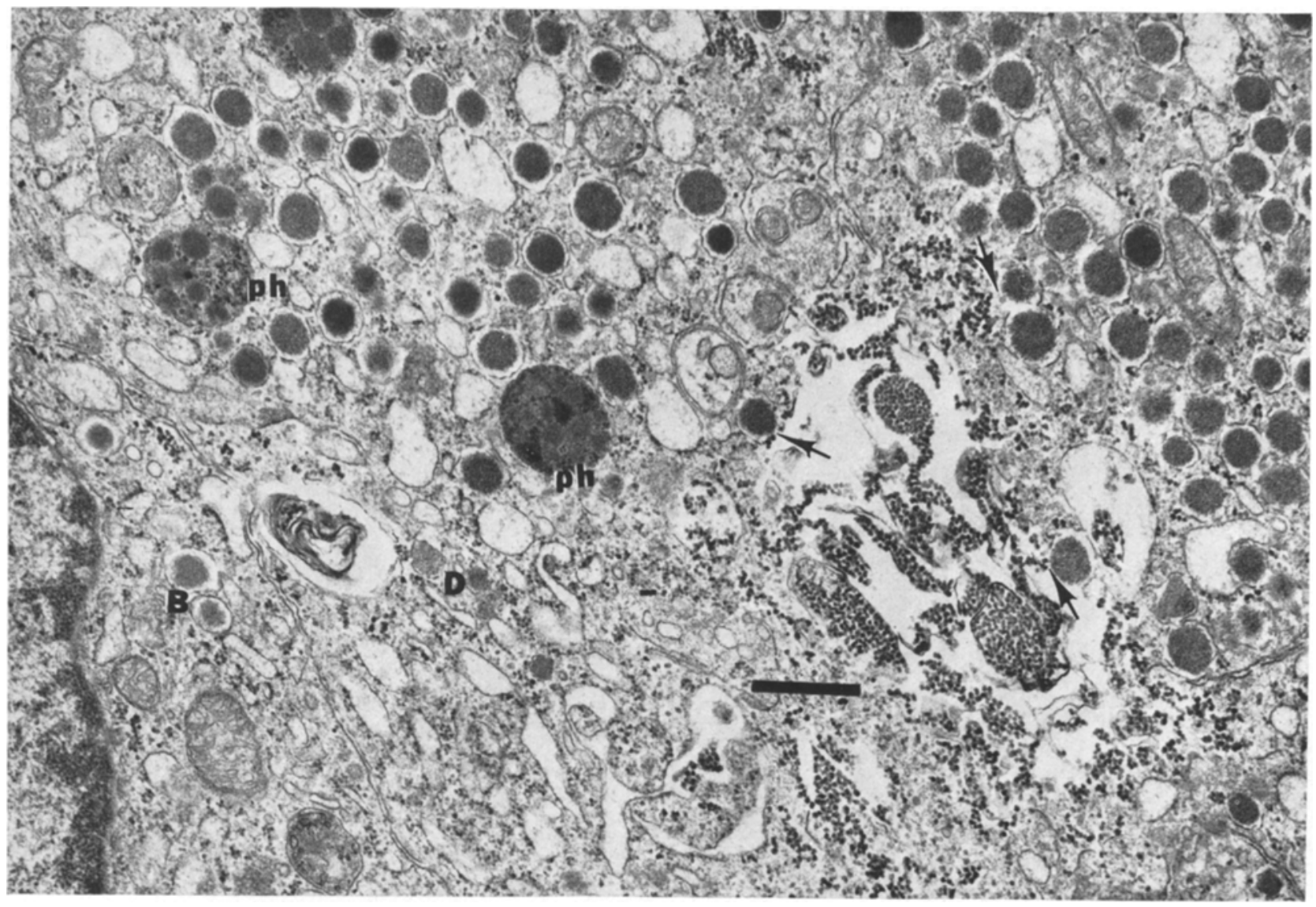


process of a bipolar cell at the center. The close contact of the bipolar dendrite with the affected cell suggests that the cell with the glycogen deposit is a Müller cell.

Frequently, deposits of $\alpha$ or $\beta$ glyeogen particles or both were found in the same retina. Fig. 6 shows a deposit of $\alpha$ glycogen rosettes measuring about $750 \AA$ found in a hamster 11 months old, 9 months diabetic and 6 months ketonuric. The intracellular character of this deposit was clear since remnants of some organelles were still visible within a well preserved cellular membrane. The capillary near the affected cell was not involved although the basement membrane, fairly uniform in thickness, showed an irregular contour. Another area of the same retina shown in Fig. 6 showed a deposit of $\beta$ glycogen particles which measured about $300 \AA$ (Fig. 7). The glycogen was intracytoplasmic although no organelles were found in the scanty cytoplasm. Possible relationship of the deposit with the Miuller cell, at right bottom, could not be established.

Another abnormality observed in the eye of some diabetics was degeneration of the expansions of the Miuller cells at the level of the nerve fiber layer (Fig. 8). Segments of cytoplasmic expansion of normal Müller cells show dispersed, monoparticulate glycogen and appear characteristically darker than other cells.

The kidneys of 99 hamsters were examined. Light microscopy showed PAS + amylase-digestible material in distal tubules near some glomeruli in all 44 ketonuric hamsters studied. Electron microscopy revealed that this material was glycogen. The glomerular basement

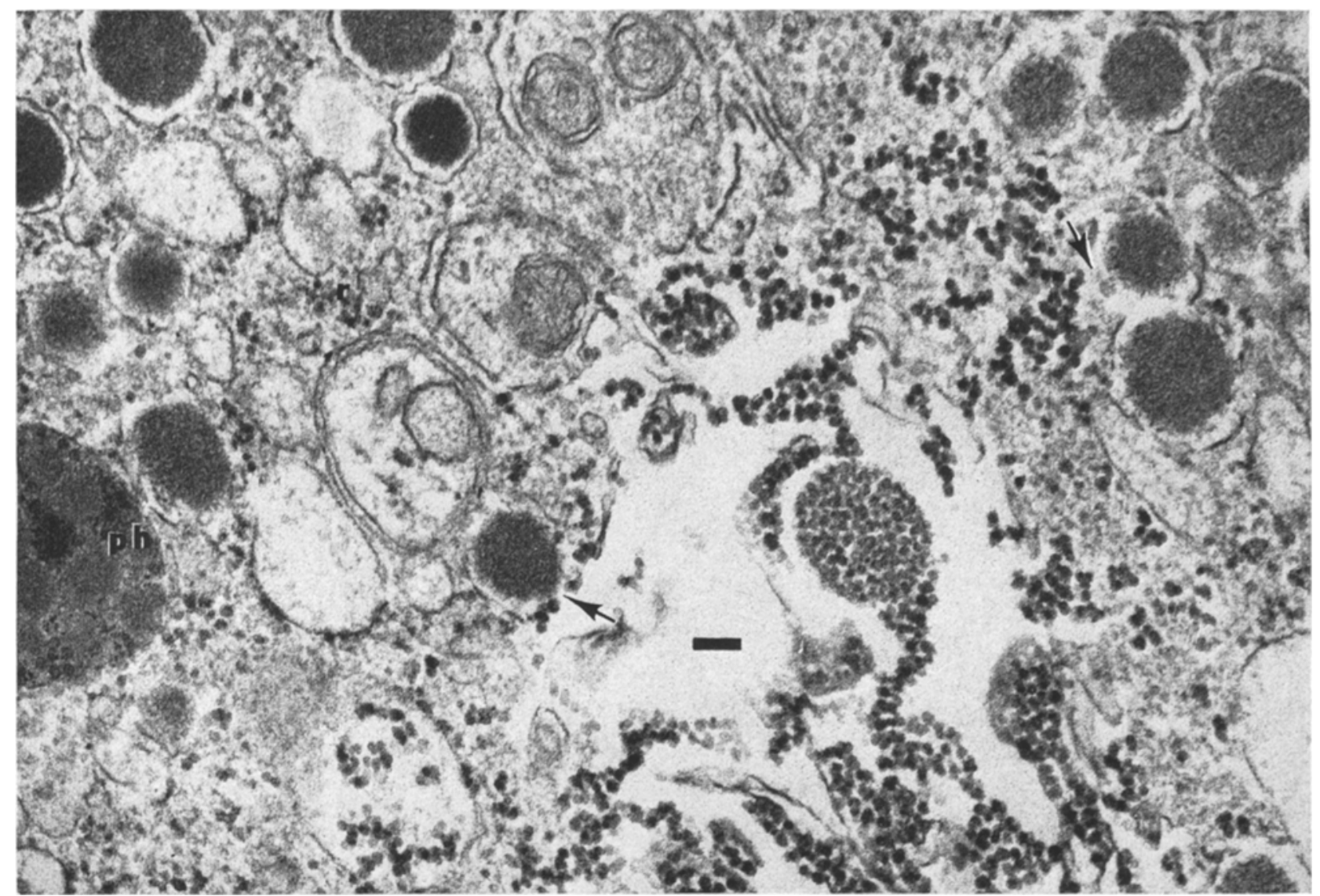

Fig. 11b) Detail of Fig. 11a, at higher magnification. Notice the close proximity of glycogen particles to $\alpha$ granules (arrows). Phagosome $=\mathrm{ph} ;$ ribosomes $=\mathrm{r} ;$ Bar $=0.1 \mu$

Fig. 12a and 12b. Pancreatic D cell from the same Chinese hamster of Fig. 11

Fig. 12a) Glycogen particles and disintegrating glycogenosomes in a $D$ cell (D). To the right of center, a degranulated $\beta$ cell $(B)$ showing typical phagosomes ( $p h$ ) of diabetic hamsters. An $\alpha$ cell at top left (A). Notice the different electron density of $\alpha, \beta$, and $D$ granules. The membranes separating $\alpha$ and $D$ cells are indicated by double arrows. The membranes of $\mathrm{D}$ and $\beta$ cells are indicated by single arrows. Bar $=0.5 \mu$

Fig. 12b) Detail of Fig. 12a, showing the proximity of glycogen particles to $D$ granules. Notice the characteristic finely granular, medium low density structure of $D$ granules, and the narrow space between granule membrane and core. $\mathrm{Bar}=0.1 \mu$ 


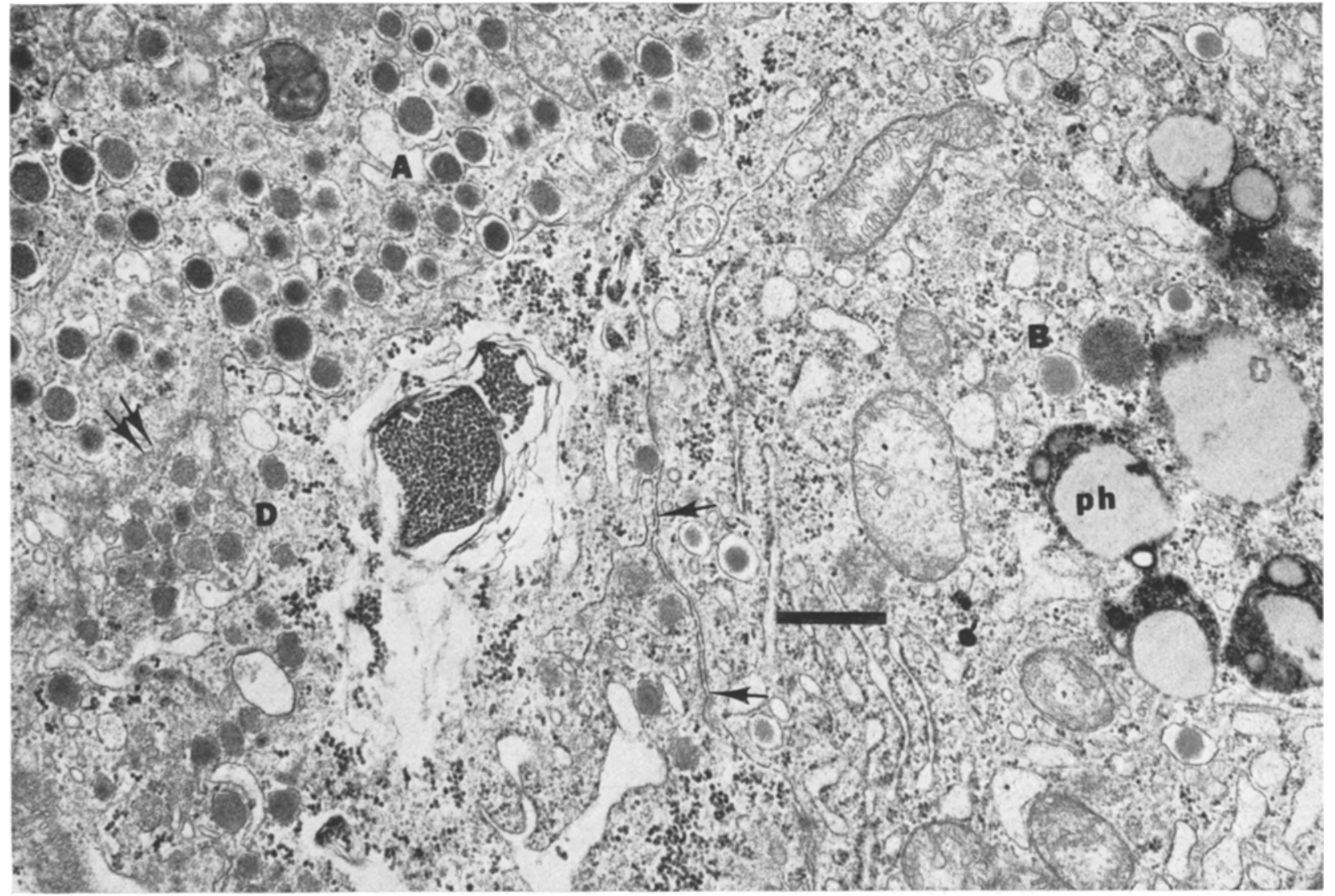

Fig. 12a

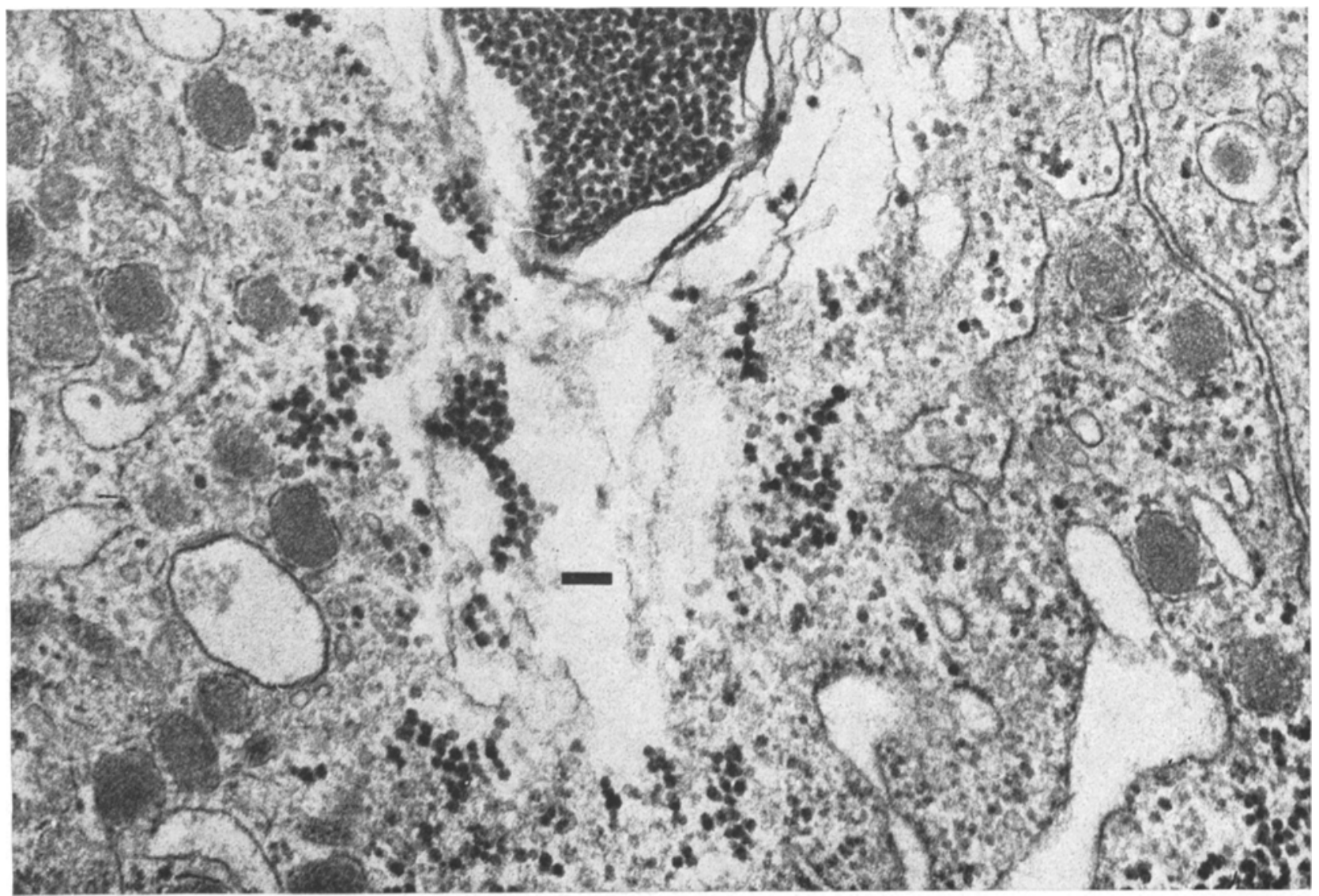


membrane was not thickened but the subepithelial side was slightly irregular. The mesangium was moderately enlarged in a few areas, which accounted for the enhanced PAS + staining observed with light microscopy. Glycogen was observed in the Bowman space and in the collecting tubules at the papilla, in variable amounts in diabetics and nondiabetics.

Light microscopy of pancreatic islets from 39 ketonuric Chinese hamsters showed the typical $\beta$ cell degranulation, giycogen deposition and vacuolation. In these animals, the islets were scarce and usually small compared with those of the 38 nondiabetics examined.

When studied with the electron microscope, it was found that in diabetic animals the number of $\beta$ cells per islet was diminished, the frequency of $\beta$ granules per cell was quite low and the few granules observed were of low electron density (Fig. 9). However, the $\beta$ cells of diabetics presented a well developed Golgi apparatus and numerous stacks of rough endoplasmic reticulum (RER) which suggested that these cells were quite active. Dispersed glycogen granules were observed in most $\beta$ cells and masses of glycogen were found in a few. In such $\beta$ cells the phagosomes were larger, more frequent and characteristically loaded with accumulations of lipofuscin (Fig. 12a).

Fully granulated $\alpha$ cells in diabetic hamsters were more apparent due to decrease in number and granulation of $\beta$ cells. The rough endoplasmic reticulum did not appear in stacks but in isolated and infrequent profiles. In long term ketonurics, the RER cisternae of $\alpha$ cells were dilated and contained an amorphous material. Dense phagosomes, occasionally found in normal $\alpha$ cells, were frequent and large in $\alpha$ cells of diabetic hamsters. In these cells the enlarged phagosomes had numerous dense granules of variable size but not larger than the dense core of the $\alpha$ granules.

Alpha and D cells of two Chinese hamsters $13-14$ months old, 12 months diabetic and ketonuric less than 2 months had a very unusual glycogen deposition, as shown in Figs. 10,11a and 12a. Thorough examination of the material indicates that the glycogen was indeed within $\alpha$ and $\mathrm{D}$ cells, in close proximity to the $\alpha$ and D granules (Figs. $11 \mathrm{~b}$ and 12b).

The identity of $\alpha$ cells was established by the presence of typical $\alpha$ cell phagosomes (Fig. 11) and of dense perinuclear fibrillar bundles (Fig. 10) which are rarely observed in Chinese hamster $\beta$ cells (Fig. 9) and then only in thin bundles. D cell granules have a distinct finely granular, medium electron density structure and the granule membrane is separated from the core by a uniformly narrow space.

\section{Discussion}

Morphologic changes associated with abnormal glycogen deposition have been observed in retinal, pancreatic and renal tissues from spontaneously diabetic Chinese hamsters. It appears that the incidence of retinal lesions correlates with severity of diabetes since the incidence was highest in animals with continuous ketonuria and decreased with decreasing severity of diabetes. However, lesions were found in a few hamsters that never had ketonuria, but only after 10 months of continuous glucosuria. It appears that sex and age, up to 28 months, are not major contributing factors for development of these abnormal deposits. Observations to date do not suggest retinal vessels are directly involved in the formation of or connected to the retinal deposits of glycogen. The type or types of retinal cells with abnormal glycogen deposits have not been clearly established. It should be pointed out that the retinal cells with glycogen deposits have morphologic characteristics of Müller cells because of their contact with neurons. However, perivascular processes of Müller cells have thus far been found free of abnormal glycogen deposition. It may be that this area of the Müller cells has functions other than synthesis and storage of glycogen. The concept of abnormal glycogen deposition in Müller cells is supported by the observation that monoparticulate glycogen occurs in Müller cells of nondiabetic Chinese hamsters and has also been reported in other species by Kuwabara and Cogan [8]. Therefore, it is reasonable to expect a metabolic disorder such as diabetes mellitus to result in increased amounts of intracellular glycogen. It is unknown if this deposit is due to increased synthesis and/or decreased catobolism of glycogen.

Abnormalities found in the kidneys of diabetic hamsters were qualitatively similar to those reported by Shirai [14] and Conforti [5]. However, changes observed were quantitatively less. This could be due to younger animals with a shorter duration of diabetes in this study. Contrary to Conforti's observation that glycogen deposition in the epithelial cells of the collecting tubules of the papilla was associated with diabetes, glycogen was formed in these cells from nondiabetics and diabetics. This has also been reported in human kidney cells [1]. Glycogen deposition in the distal tubules was found only in ketonuries, but grades of thickening of mesangium and irregularities of glomerular basement membrane contour could not be correlated with duration or severity of diabetes. It should be pointed out that none of these changes were observed in nondiabetics.

Changes in pancreatic islets including glycogen deposition in $\beta$ cells were similar to those reported by others $[2,3,4,10,13]$. However, finding of glycogen in $\alpha$ and $D$ cells in ketonuric diabetics is of considerable interest since it has not been described previously. The tissues in which these new observations were made were from rather atypical animals since they were diabetics for approximately one year before development of ketonuria. They were killed within two months after onset of ketonuria. Since glycogen deposition has not been observed in $\alpha$ and $D$ cells of 
long duration ketonuries, glycogen deposition in $\alpha$ and $D$ cells may be a transient condition associated with recent onset of ketonuria in the middle aged, long term glucosuric Chinese hamster.

The consistent finding of glycogen deposits within cells of tissues which are primarily affected by diabetes, such as the retina, kidney and pancreatic islet makes it tempting to speculate that abnormal glucose and glycogen metabolism may play an important role in the pathogenesis of diabetes in the Chinese hamster.

Acknowledgment. The authors wish to acknowledge the assistance of Edward M. Block, Pathology and Toxicology Research Unit, The Upjohn Company, Kalamazoo, Michigan with the photography in this paper.

\section{References}

1. Biava, C., Grossman, A., West, M.: Ultrastructural observations on renal glycogen in normal and pathologic human kidneys. Lab. Invest. 15, 330 - 356 (1966)

2. Boquist, L.: The endocrine pancreas of the Chinese hamster, Thesis. Umeå, Sweden: Tryckerialktiebolaget. 1969

3. Carpenter, A.M., Gerritsen, G.C., Dulin, W.E., Lazarow, A.: Islet and Beta cell volumes in offspring of severely diabetic (ketotic) Chinese hamsters and their nondiabetic siblings. Diabetologia 3, 92-99 (1967)

4. Carpenter, A.M., Gerritsen, G.C., Dulin, W.E., Lazarow, A.: Islet and Beta cell volumes in offspring of severely diabetjc (ketotic) Chinese hamsters. Diabetologia 6, 168-176 (1970)

5. Conforti, A.: Ultrastruttura del rene nel diabete spontaneo dell'hamster cinese (Cricetulus griseus). Acta diabet. lat. 9,655-687 (1972)

6. Federman, J.L., Gerritsen, G.C.: The retinal vasculature of the Chinese hamster: A preliminary study. Diabetologia 6, $186-191(1970)$
7. Gerritsen, G.C., Dulin, W.E.: Characterization of diabetes in the Chinese hamster. Diabetologia 3, 7484 (1967)

8. Kuwabara, T., Cogan, D.G.: Retinal glycogen. Arch. Ophthal. 66, 680-688 (1961)

9. Like, A.A., Gerritsen, G.C., Dulin, W.E., Gaudreau, P.: Studies in the diabetic Chinese hamster: electron microscopy of pancreatic islets

10. Luse, S.A., Caramia, F., Gerritsen, G.C., Dulin, W.E. Spontaneous diabetes mellitus in the Chinese hamster: An electron microscopic study of the islet of Langerhans. Diabetologia 3, 97-108 (1967)

11. Meier, H., Yerganian, G.A.: Spontaneous hereditary diabetes mellitus in Chinese hamster (Cricelulus griseus): I. Pathologic findings. Proc. Soc. exp. Biol. (N.Y.) 100, 810-815 (1959)

12. Orci, L., Amherdt, M., Malaisse-Lagae, F., Perrelet, A., Dulin, W.E., Gerritsen, G.C., Malaisse, W.J., Renold, A.E.: Morphological characterization of membrane systems in $A$ - and $B$-cells of the Chinese hamster. Diabetologia 10, 529 - 539 (1974)

13. Orci, L., Stauffacher, W., Dulin, W.E., Renold, A.E., Rouillier, Ch.: Ultrastructural changes in A-cells exposed to diabetic hyperglycemia. Observations made on pancreas of Chinese hamsters. Diabetologia 6, $199-206(1970)$

14. Shirai, T., Welsh, G.W., Sins, E.A.H.: Diabetes mellitus in the Chinese hamster. II. The evolution of renal glomerulopathy. Diabetologia 3, 266-286 (1967)

15. Sirek, O.V., Sirek, A.: The colony of Chinese hamsters of the C.H. Best Institute: A review of experimental work. Diabetologia 3, 65-73 (1967)

16. Soret, M.G., Dulin, W.E., Gerritsen, G.C.: Microangiopathy in animals with spontaneous diabetes. Early Diabetes. Advances in Metabolic Disorders, Supplement 2, pp. 291-298. New York and London: Academic Press 1973

Dr. M. G. Soret Pathology and Toxicology Research Unit

The Upjohn Company

Kalamazoo, Mich. 49002

UTSA 